ELORE (ISSN 1456-3010), vol. 20 - 1/2013.

Julkaisija: Suomen Kansantietouden Tutkijain Seura ry.

[http://www.elore.fi/arkisto/1_13/hamalainen.pdf]

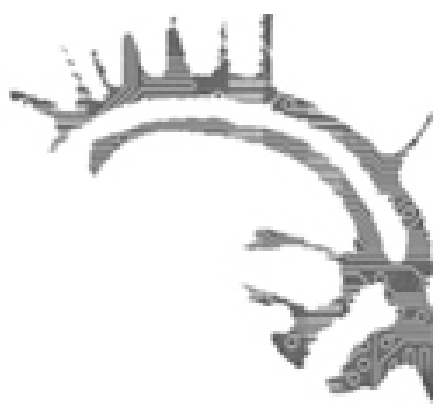

\title{
KIRJA-ARVIO
}

\section{ERI KERROKSISTA SAMAAN KOULUNPENKKIIN}

HEIKKINEN, ANJA \& LEINO-KAUKIAINEN, PIRKKO (toim.) 2011: Valistus ja koulunpenkki. Kasvatus ja koulutus Suomessa 1860-luvulta 1960-luvulle. Suomalaisen Kirjallisuuden Seuran Toimituksia 1266:2, Tiede. Helsinki: SKS. 530 sivua.

\section{Niina Hämäläinen}

Suomalaista koulujärjestelmää juhlitaan maailmalla. PISA-tutkimuksen ensimmäinen sija nousee esiin keskusteluissa lasten koulutuksesta ja opiskelumahdollisuuksista. Esimerkiksi Luxemburgissa, jossa olen asunut viimeiset 11 vuotta, suomalainen koulu on symboli menestykselle ja sivistykselle, samalla kun paikallinen koulujärjestelmä pyristelee alhaisten tulosten varjossa. Valistus ja koulunpenkki. Kasvatus ja koulutus Suomessa 1860-luvulta 1960-luvulle -teos piirtää yksityiskohtaisen kuvan nykyisen koulujärjestelmämme historiasta aina kansakoulun alkuajoista oppikoulun ja ammatillisen opetuksen painottamaan moderniin yhteiskuntaan. Tie ei ollut suora saati kuopaton. Sen sai kokea Seitsemän veljeksen (1870) Juhanikin, jolle lukkarin ovi oli surman kita.

Valistus ja koulunpenkki on toinen osa kronologisesti etenevää Suomalaisen Kirjallisuuden Seuran kustantamaa ja Suomen Historiallisen Seuran toimittamaa Suomen kasvatuksen ja koulutuksen historia -sarjaa. Kirjoittajat ovat pääasiassa historian ja kasvatustieteiden tutkijoita, vaikka ensimmäisen osan, Huoneentaulun maailma (2010), johdannossa sanotaankin sarjan kokoavan kirjoittajia eri tieteenaloilta. Ensimmäinen osa käsitteli kasvatuksen ja koulutuksen taivalta keskiajalta 1860-luvulle. Käsillä oleva toinen osa on edellistä kiinnostavampi juuri sen historiallisessa merkittävyydessä. 1860-luvulta 
lähtien luotiin paitsi suomalaisen koulutuksen perusta myös yleiset kasvatukseen liittyvät periaatteet.

\section{KESKUSTELUA, KRITIIKKIÄ JA TOISTOA}

Valistus ja koulunpenkki -teos alkaa kirjan toimittajaparin, Anja Heikkisen ja Pirjo Leino-Kaukiaisen johdantoluvulla ja artikkelilla "Yhteiskunta ja koulutus". Johdantoluvussa esitellään teoksen kantava teema, kasvatuksen ja koulutuksen tehokas yhteen liittyminen suomalaisessa kontekstissa. Ilman ristiriitoja koulutuksen alkuaikoja ei taivallettu, ja teoksen päämääränä on valaista keskusteluja, kritiikkiä ja ristiriitoja, joita muutosprosessi aiheutti sekä kertoa sen tuloksista ja merkityksistä (s. 13). Tässä teos onnistuu monipuolisesti ja yksityiskohtaisesti.

Teos jakaantuu johdantoon ja neljään pääosaan: "Koulutus kamppailujen tuloksena”, "Kasvatuksen ihmiskäsitykset ja ihanteet" "Kasvattajuus yhteiskunnallisena ja opillisena projektina" ja "Kasvatuksen sosiaaliset merkitykset". Kokonaisuudessaan teos valottaa kansallisia tavoitteita, modernisoitumisen kuoppia, sosiaalisia eroja ihmisten välillä sekä kasvatukseen eri aikoina liittyviä ongelmia ja kysymyksiä monelta kannalta ja moneen kertaan. Toistoa olisi voinut karsia ja välttää artikkelien toisenlaisella tematisoinnilla. Sisällysluettelon lukuisat alaotsikot ovat informatiivisia ja tiiviitä, mutta erilliset luvut eivät tahdo nousta kunnolla esiin, vaan ne puuroutuvat tekstin virtaan. Näin tapahtuu paikoin tekstinkin tasolla, vaikkakin kärsivällinen lukeminen myös palkitaan asiantuntevilla katsauksilla.

\section{KAHDEN KOULUTUKSEN VÄKI}

Kahden sivistyksen koulutus on yksi keskeinen suomalaista varhaista koulutusjärjestelmää luonnehtiva seikka. Marja Jalava tarkastelee artikkelissaan kansanopetuksen murrosta ja ajatuksia, jotka johtivat vuonna 1866 kansakouluasetukseen. Snellmannin näkemys "ei koulu sentään ihmistä tee" (s. 77), vaan perhe ja siveellinen kotikasvatus, sai tuolloin rinnalleen Cygnaeuksen idean koulusta kotikasvatuksen ja lastenhoidon uudistajana. Cygnaeuksen moderni ajatus leikistä lasten työnä ja koulusta lasten työpaikkana ei kuitenkaan miellyttänyt sivistyneistöä. Yhtenäisen opetuksen koulun idea hiipui Cygnaeuksen kuoleman jälkeen 1888, ja sivistyneistön piirissä alettiin suosia oppikoulujen erillisjärjestelmää.

Suurin ongelma varhaisessa koulunkäynnissä nähtiin koulutusvastuussa ja -laajuudessa: kenen tehtävä oli huolehtia kansanopetuksesta modernissa yhteiskunnassa? Entä kenelle koulusivistys kuului? Nämä ongelmat tulevat hyvin esitellyiksi Saara Tuomaalan artikkelissa "Kamppailu yhteisestä koulusta ja oppivelvollisuudesta". Vaikka nyky-Suomi voi ylpeillä korkeasti koulutetulla väestöllä, tuli Suomessa kaikkia kansalaisia koskeva oppivelvollisuuslaki voimaan länsimaisittain vasta niinkin myöhään kuin vuonna 1921. Oppivelvollisuuden rakentaminen oli kytköksissä modernin lapsuuden ideaan, joka 
nimitettiin "normaalin lapsuuden luomiseksi” (s. 105). Tämä tarkoitti käytännössä sitä, että mahdollisimman laajalle osalle kouluikäisiä tarjottiin mahdollisuus koulunkäyntiin. Hieno periaate kätki sisäänsä ideologisen tavoitteen vaalia tervettä ja voimakasta kansanruumista. Tämän seurauksena vapautuksia koulunkäynnistä annettiin vähävaraisille, heikon terveyden omaaville tai "heikkolahjaisille".

Koulutuseroja käsittelevät artikkeleissaan myös Annukka Jauhiainen ja John Strömberg. Jauhiainen korostaa koulutuksen sosiaalista ja alueellista eriarvoisuutta, joka jatkui 1970-luvulle peruskoulu-uudistukseen saakka. Strömbergin artikkeli kertoo ruotsinkielisen koulun historiaa, joka jää teoksessa muuten suomenkielisen koulunkäynnin varjoon. Kun koulujärjestelmän kehityksessä ajettiin suomenkielistä opetusta kouluihin mahdollistamaan laajan kansanosan koulunkäynnin, säilyi ruotsinkielisillä omat koulut, vaikkakin niissä noudatettiin ja noudatetaan edelleen samaa koulutussuunnitelmaa kuin suomenkielisissä. Ruotsinkielisten koulujen eriytymistä erillisiksi kouluiksi ja koulujen suhteellisen korkeaa tasoa tai vakavaraisuutta on pidetty Suomessa kielipoliittisena tai vähemmistökysymyksenä, vaikka 1800-luvulla kyse oli myös yhteiskuntapolitiikasta.

\section{KOULUTUS ALKAA ÄIDISTÄ}

Terveyden ja kasvatuksen ihanteita valotetaan teoksen toisessa osiossa "Kasvatuksen ihmiskäsitykset ja ihanteet”. Leena Koski käsittelee 1800-luvun sivistyneen ja siveellisen kansalaisen ideaa, joka pohjautui ajatukseen vajavaisesta rahvaasta valistusta ja opastusta kaipaavana kohteena. Kosken artikkelissa tulee esiin myös äidin merkittävä osuus varhaisessa kasvatusideassa. Kirjan kansi, naispuolinen opettaja (opettajatar) ohjaamassa pulpetissa istuvia lapsia, kiteyttää oivallisesti teoksen historiallisen kontekstin: äiti on ollut lapsen ensimmäinen sekä lähin kasvattaja ja kansakoulussa opettajana oli sama, äidillinen hahmo. Opettajan toimi oli harvoja kunniallisia toimia säätyläisnaisille. Säätyläisopettajien toivottiin myös tuovan sivistyneistön tapoja ja arvoja maaseudun rahvaan keskuuteen, kuten Jukka Rantala artikkelissaan kansakouluopettajista kertoo.

Äidin kasvatusvastuuta painotettiin yhä enenevässä määrin 1800-luvun porvarillisen perhekeskustelun myötä. Tämän seurauksena naisille alettiin vaatia yhä voimakkaammin mahdollisuutta koulunkäyntiin. Esimerkiksi Elias Lönnrot puolusti naisen sivistämistä koulutuksella ja vaati tytöille ja pojille samanlaista opetusta. Tyttöjen koulunkäynnin tarpeellisuutta hän perusteli naisen luontaisella kutsumuksella perheen parissa, ei suinkaan naisen mahdollisuutena kodin ulkopuoliseen työelämään: "Eikö vaimopuoli siis tarvitse'kaan oppia? Tarvitseepa kyllä, ja juuri siitä syystä, kun äiti on lähin lapsensa opettaja, tarvitseisi hän sitä enemmin kuin miehenpuolet tarvinne'kaan." (Litteraturblad 1847:1 / VT 4: 216.)

Naissivistykseen kietoutui käsitys siveellisestä, aseksuaalisesta naisesta, perheen äidistä, joka huolehtii lastensa ja aviomiehensä hyvinvoinnista. Siveellisyyden käsite sisälsi ajatuksen puhtaudesta niin fyysisessä kuin moraalisessa mielessä, joka kiteytyi kuvaan ideaalisesta äidistä tai vastaavasti kansakouluopettajasta, joka oli ahkera, hurskas ja tunteensa hillitsevä lasten esikuva (s. 279). Naisten sivistystyötä on ahkerasti ylläpitänyt 
Lucina Hagmanin vuonna 1899 perustama järjestö “Sivistystä kodeille”, joka sittemmin on kantanut nimeä Marttajärjestö tai Marttaliitto. Marttaliitosta olisi voinut hyvinkin toimittaa oman artikkelinsa, jossa olisi käsitelty kasvatuksen ja koulutuksen ihanteiden muutoksia ja ristiriitoja marttojen näkökulmasta. Tässä tulee myös esiin Valistus ja koulunpenkki -teoksen yksi ongelmista. Koska on haluttu mahdollisimman kattavasti tarkastella koulutukseen liittyviä historiallisia, sosiaalisia ja kulttuurisia eroja, ristiriitoja ja muutoksia, ei teoksessa ole tilaa pysähtyä tarkemmin jonkun osa-alueen kohdalla.

\section{KOULUTUKSEN MUUTOS JA YHTENÄISTYMINEN}

Koulutuksen historiassa myös terminologia ja asenteet muuttuivat. Koulunkäynnin alkutaipaleilla 1800-luvulla korostettiin koulutusta kasvatuksen lisänä, jonka tarkoituksena oli valistaa ja sivistää oppimatonta rahvasta. Vielä tuolloin olivat näkyvissä erot eri yhteiskuntaluokkien kesken, vaikka ei voitukaan enää puhua säätyihin perustuvasta koulutuksesta. Edelleen moni lapsi ohjattiin pysymään säätynsä rajoissa. 1900-luvun aikana valistuksen ja siveellisen kasvatuksen rinnalle tuli tietoon perustuva kasvatus. Koulusta kehkeytyi tiedon tyyssija, josta lapsi ja nuori saa mahdollisimman monipuoliset tiedon eväät omalle elämälleen.

Kiinnostavan lisän kasvatukseen historiaan pedagogisena ja yhteiskunnallisena projektina luo teoksen kolmas osio, joka ainakin minulle toi aivan uutta tietoa ja näkökulmaa eri koululaitoksiin. Myös opettajien koulutuksessa tapahtuneet muutokset ovat erinomainen lisä kasvatuksen kokonaiskuvassa. Johdannossa esitelty keskeinen linjakysymys: "millainen oli eri yhteiskuntaryhmien mahdollisuus ja tarve koulumaiseen kasvatukseen" (s. 13) valottuu erilaisten opinahjojen esittelyillä. Kahden koulutuksen ongelma näkyy tässäkin. Kaikille yhteisen ja pakollisen kansakoulun jälkeen oppilaat eriytyivät jo varhain joko kansalaiskouluun, joka vastasi nykypäivän ammatillista koulutusta ja yliopisto-opintoihin johtavaan oppikouluun. Teoksen neljäs osio, sinällään kiinnostava ja ajatuksia herättävä "Kasvatuksen sosiaaliset merkitykset" on monelta osin päällekkäinen muiden osioiden kanssa.

Hyvä henkilöhakemisto auttaa lukijaa löytämään etsimänsä 500 sivun mittaisesta teoksesta. Asiasanahakemisto olisi tuonut lisävaloa eri kasvatuksen ja koulutuksen osaaluiden esiintymisiin teoksen lukuisissa artikkeleissa. Mittavuudessaan teoskokonaisuus on ansiokas, mutta lukija jää kaipaamaan "pieniä tarinoita”, ihmiskohtaloita, anekdootteja, muistelmia, jotka olisivat avartaneet konkreettisilla, ihmisten omakohtaisilla kokemuksilla historian laajaa kaarta. Tietolaatikoiden ja kuvien määrää olisi hyvinkin voinut lisätä, jolloin teoksen luonne kasvatuksen ja koulutuksen tietopakettina ja hakuteoksena olisi kirkastunut. Värikuvituskin olisi tuonut valoa. Miksi kasvatuksen ja koulutuksen historian kaksi ensimmäistä osaa ovat väriltään mustavalkoisia? Onko värivalinnalla haluttu korostaa alkutaipaleen ankeutta ja vaikeutta? Jos verrataan teossarjaa niin ikään SKS:n kustantamaan Suomen Kirjallisuushistoriaan (1999) on ero sekä ulkoasussa että tematisoinnissa jälkimmäisen eduksi. Kasvatus ja koulutus antaa kuitenkin laajan ja monipuolisen kuvan paitsi kasvatuksen monipolvisesta historiasta myös suomalaisen yhteiskunnan vähittäisestä modernisoitumisesta keskiajalta 2000-luvulle. 


\section{ONKO YHTEINEN KOULUTUS MAHDOLLINEN KAIKILLE MYÖS TULEVAISUUDESSA?}

Suomessa kehittyi 1960-luvulle tultaessa tasa-arvoon ja yhtenäiseen opetusjärjestelmään perustuva koululaitos, joka takasi kaikille lapsille ja nuorille mahdollisuuden koulunkäyntiin. PISA-tutkimuksen valossa suomalainen koulujärjestelmä on ensiluokkainen ja mahdollistaa edelleen kaikille yhtenäisen koulutuksen. Tutkimus ei kuitenkaan kerro koko totuutta. Vaikka Suomi on eurooppalaisesta näkökulmasta homogeeninen maa myös sosiaalisessa mielessä, on esimerkiksi pääkaupunkiseudulla näkyvissä eriarvoistumista koulunkäynnissä. Tästä ovat tuoreena esimerkkinä viime syksyn Helsingin Sanomien kirjoitukset kouluavustajien ja lisätuen tarpeesta tavallisilla koululuokilla (HS esim. 28.9.2012, 22.10.2012, 3.11.2012). Pystyykö koulutusjärjestelmämme takaamaan vastaisuudessakin tasa-arvoisen ja kaikille yhtenäisen koulutien vai palautuuko ajatus kahden koulutuksen väestöstä suomalaiseen yhteiskuntaan? Kasvatuksen ja koulutuksen historian kolmas osa Tiedon ja osaamisen Suomi (2012) ainakin nimensä perusteella tuntuu uskovan julkisen koulutusjärjestelmämme säilymiseen.

\section{KirJallisuUs}

EI KIRJOITTAJAA 2012: Tavallisten oppilaiden asiaa ei aja kukaan. - Helsingin Sanomat 22.10.2012. [online] <http://www.hs.fi/paivanlehti/mielipide/Tavallisten +oppilaiden+asiaa+ei+aja+kukaan/a1350786965954> [4.3.2013.]

EI KIRJOITTAJAA 2012:Vanhemmat, vaatikaa lapsillenne oikeuksia! - Helsingin Sanomat 3.11.2012. [online] <http://www.hs.fi/paivanlehti/mielipide/Vanhemm at+vaatikaa+lapsillenne+oikeuksia/a1351832972153> [4.3.2013.]

HANSKA, JUSSI \& VAINIO-KORHONEN, KIRSI (toim.) 2010: Huoneentaulun maailma. Kasvatus ja koulutus Suomessa keskiajalta 1860-luvulle. Helsinki: SKS.

KETTUNEN, PAULI \& SIMOLA, HANNU (toim.) 2012: Tiedon ja osaamisen Suomi. Kasvatus ja koulutus Suomessa 1960-luvulta 2000-luvulle. Helsinki: SKS.

KIVI, ALEKSIS 1993: Seitsemän veljestä. Helsinki: Otava. [1870]

LAITA, SAMULI, SIPPOLA, ANNA-RIITTA 2012: Vaarana koulujen valikointi Helsingin Sanomat 28.9.2012. [online] <http://www.hs.fi/paivanlehti/kaupunki/ Vaarana+koulujen+valikointi/a1348718096552> [4.3.2013.]

LÖNNROT, ELIAS 1992: Valitut teokset 4: Ohjeita ja runoelmia (VT 4) (toim. Raija Majamaa). Helsinki: SKS.

VARPIO, YRJÖ (toim.) 1999: Suomen Kirjallisuushistoria 1-3. Helsinki: SKS. 1999.

Filosofian tohtori Niina Hämäläinen on folkloristiikan tutkija. 